\title{
Has Urine Protein Any Correlation with Height Phobia?
}

\author{
Muhammad Imran Qadir, Adeeba Shahid, Hira Mumtaz* \\ Institute of Molecular Biology and Biotechnology, Bahauddin Zakariya University, Multan, Pakistan
}

*Corresponding Author: Hira Mumtaz, Institute of Molecular Biology and Biotechnology, Bahauddin

Zakariya University, Multan, Pakistan.

\begin{abstract}
The correlation of urine protein with acrophobia is the main objective of this study. The 0-20mg/dl are the normal values for urine sample. Adequate amount of protein does not pass through the kidney filters, when the kidney is healthy. Due to overproduction of protein by body, peoteinuria occurs. Acrophobia is a common fear from height. The people that are suffering from height phobia feel themselves in danger at a certain height from ground level. Urine test was made to know about the protein level in urine. Questions were asked from students about height phobia. Then height phobia was related with urine protein. Correlation of acrophobia with protein in urine was deduced from this study.
\end{abstract}

Keywords: urine protein, height phobia, damaged kidney filters.

\section{INTRODUCTION}

The $0-20 \mathrm{mg} / \mathrm{dl}$ are the normal values for urine sample. Adequate amount of protein does not pass through the kidney filters, when the kidney is healthy. When the kidney filters are damaged due to the kidney disease, the protein like albumin may be secreted into the urine from blood. Due to overproduction of protein by body, peoteinuria occurs. It is also known as albuminuria. In proteinuria, the abnormal level of protein is present in the urine. It is a symptom of kidney disease. Diabetes and hypertension are risk factors for proteinuria. Obesity and age over 65 are also other risk factors for albuminuria. Appropriate medication is necessary for the treatment of it. In some cases, the drugs are taken like ACE inhibitors. Urine test is performed to measure the amount of protein in urine.

Acrophobia is a common fear from height. The people that are suffering from height phobia feel themselves in danger at a certain height from ground level. They feel uncomfortable and it becomes difficult to regulate the balance.Some factors influence on height phobia like environmental factors. Acrophobia disturbs the activities of people who are suffering from it.

The correlation of urine protein with acrophobia is the main objective of this study.

\section{Materials AND Methods}

The number of students that are involved in this study were 100. They were related to Bahauddin Zakariya University, Multan, Pakistan. Urine test was made to know about the protein level in urine. Questions were asked from students about height phobia. Then height phobia was related with urine protein.

\section{RESUlT AND DisCUSSION}

Has urine protein any correlation with acrophobia is given in table. Protein in urine was found in $15 \%$ male and $11.25 \%$ females and it was not found in $85 \%$ males and $66.25 \%$ femals, but they all suffered from height phobia. Protein in urine was found in $3.75 \%$ female and not found in $18.75 \%$ females, they did not suffer from height phobia.

\begin{tabular}{|l|l|l|l|l|}
\hline Gender & \multicolumn{2}{|c|}{ Height phobia } & \multicolumn{2}{c|}{ No height phobia } \\
\hline & Protein in urine present & Protein in urine absent & Protein in urine present & Protein in urine absent \\
\hline Male & $15 \%$ & $85 \%$ & $0 \%$ & $0 \%$ \\
\hline Female & $11.25 \%$ & $66.25 \%$ & $3.75 \%$ & $18.75 \%$ \\
\hline
\end{tabular}




\section{CONCLuSion}

Correlation of acrophobia with protein in urine was deduced from this study. It showed great affiliation.

\section{REFERENCES}

[1] Qadir MI, Malik SA (2010) Comparison of alterations in red blood cell count and alterations in hemoglobin concentration in patients suffering from rectal carcinoma undergoing 5-fluorouracil and folic acid therapy. Pharmacologyonline, Nl 3: 240-243.

[2] Qadir MI, Noor A (2018) Anemias. Rare \& Uncommon Diseases. Cambridge Scholars Publishing. Newcastle, England. ISBN: 978-1-5275-1807-0.

[3] Qadir MI, Javid A (2018) Awareness about Crohn's Disease in biotechnology students. GloAdv Res J Med Medical Sci, 7(3): 062-064.

[4] Qadir MI, Saleem A (2018) Awareness about ischemic heart disease in university biotechnology students. GloAdv Res J Med Medical Sci, 7(3): 059-061.

[5] Qadir MI, Ishfaq S (2018) Awareness about hypertension in biology students. Int J Mod Pharma Res, 7(2): 08-10.

[6] Qadir MI, Mehwish (2018) Awareness about psoriasis disease. Int J Mod Pharma Res, 7(2): 17-18.

[7] Qadir MI, Shahzad R (2018) Awareness about obesity in postgraduate students of biotechnology. Int J Mod Pharma Res, 7(2): 14-16.

[8] Qadir MI, Rizvi M (2018) Awareness about thalassemia in post graduate students. MOJ Lymphology\&Phlebology, 2(1): 14-16.

[9] Qadir MI, Ghalia BA (2018) Awareness survey about colorectal cancer in students of M. Phil Biotechnology at BahauddinZakariya University, Multan, Pakistan. Nov Appro in Can Study, 1(3): NACS.000514.2018.

[10] Qadir MI, Saba G (2018) Awareness about intestinal cancer in university student. Nov Appro in Can Study, 1(3): NACS.000515.2018.

Citation: Hira Mumtaz et al., "Has Urine Protein Any Correlation with Height Phobia?", International Journal of Research Studies in Biosciences, 8(5), pp. 13-14. DOI: https://doi.org/10.20431/23490365.0805003

Copyright: ( $) 2020$ Authors, This is an open-access article distributed under the terms of the Creative Commons Attribution License, which permits unrestricted use, distribution, and reproduction in any medium, provided the original author and source are credited. 